\title{
ANALISIS KUALITAS BAKTERIOLOGIS ESBATU DI LINGKUNGAN PASAR KOTA GEDE YOGYAKARTA
}

\author{
Warsiyah*, Warniningsih* $^{*}$ \\ *Teknik Lingkungan Institut Teknologi Yogyakarta
}

\begin{abstract}
INTISARI
Es batu sebagai bahan pendingin makan dan minuman yang langsung dikonsumsi oleh masyarakat dan digemari baik yang dijajakan di pasar tradisional, secara keliling, perumahan penduduk, di pinggir jalan raya hingga kesekolahsekolah. tempat jualan yang tidak terkoordionir, berpindah-pindah, peralatan yang tidak bersih, tidak mencuci tangan sebelum berjualan, dan penjaja yang tidak memperhatikan kebersihan, menyebabkan dagangan yang dijual tidak memenuhi syarat kesehatan. dengan kondisi demikian kemungkinan besar es batu dapat tercemar coli tinja dalam es batu. Tujuan dari penelitian ini adalah untuk mengetahui tentang kandungan colitinja pada es batu yang dijajakan.Metode penelitian yang digunakan dengan mengadakan survai yang didiskriptifkan dan analisa laboratorium kandungan colitinja pada es batu.

Hasil laboratorium menunjukkan bahwa es batu yang dijajakan di lingkungan pasar Kota Gede masih mengandung colitinja di atas 0 MPN/ ( Most Probable Number ) /100 ml. Dengan demikian menunjukkan bahwa pada hasil survai dan analisa laboratorium es batu yang dijajakan pedagang baik pengepul es, pengecer es, dan industri rumah tangga tidak memenuhi syarat kesehatan sesuai dengan Kepmenkes RI.No. 942/Menkes/SK/II/2003 dan Kepmen RI. No.907/Menkes/SK/VII/2002. baik cara penyimpanan, tempat, alat penutup es batu yang digunakan. Berdasarkan hasil tersebut diharapkan pada pedagang dalam melakukan pengolahan, pengumpulan, penyimpanan, penyajian es batu lebih ditingkatkan dan diperhatikan kebersihannya.
\end{abstract}

Kata kunci : Es batu, sanitasi, colitinja

\section{ANALYSIS OF BACTERIOLOGICAL QUALITY OF ICE CUBES IN KOTA GEDE MARKET}

\begin{abstract}
Ice cubes as a cooling material for foods and beverages are consumed directly and well loved by the people. They are available in traditional markets, sold around the residential population, at the streets and even at schools. Things in sales, such as selling - uncoordinated, moving door to door, unclean equipment, and unclean hands before selling, and ignored hygiene standards; they are exposed to violation of health requirements. Under these conditions, there is more possibility of the ice cubes contaminated by Coli bacteria.The purpose of this study is to determine the content of Coli in ice cubes that are sold. The method used is descriptive and laboratory analysis of Coli content in ice cubes.

The laboratory results show that the ice cubes sold in the market of Kota Gede still contains Coli of above O MPN (Most Probable Number) / $100 \mathrm{ml}$. Thereby it indicates that the ice cubes provided by sellers, ice cubes traders, wholesalers, retailers and domestic industries do not meet the health requirements in accordance with Kepmenkes RI.No. 942 / Menkes / SK / II / 2003 and Kepmen RI. 907 / Menkes / SK / VII / 2002 in terms of how to store, prepare the location, and ice cubes
\end{abstract}


closer.Based on these results, the traders in doing their preparation, collection, storage, and presentation of the ice cubes need to be further improved and considered clean.

Keywords: Ice Cube, Sanitation, Coli Bacterial

\section{A. PENDAHULUAN}

Kebutuhan es sebagai bahan pendingin makanan dan minuman yang langsung dikonsumsi terus meningkkat. Bahan pendingin es batu harus memenuhi persyaratan yang telah ditetapkan dalam Keputsan Menteri Kesehatan KepMenKes RI No. 907/MENKES?SK/VII/2002 tentang syarat-syarat dan Pengawasan Kualitas Air Minum dan SNI 01 3839 - 195 tentang mutu es batu. Dengan persyaratan mutunya ditinjau dari segi cemaran mikrobiologi tidak diperbolehkan adanya cemaran bakteri coliform total dalam $100 \mathrm{ml}$ sampel. Namun kenyataannya banyak produsen es batu yang kurang memperhatikan persyaratan tersebut (Anonim, 1995). Dalam rangka mewujudkan citra lingkungan masyarakat yang sehat diperlukan program jaminan pengelolaan lingkungan yang sehat dan berkelanjutan. Hal ini sejalan dengan usaha untuk mendukung visi pembangunan kesehatan menuju Indonesia Sehat 2011.Selain itu keberadaan Provinsi DIY sebagai salah satu destinasi utama di Indonesia memerlukan kajian sanitasi minuman es batu di masingmasing lingkungan warung untuk mendukung dan meningkatkan derajat kesehatan masyarakat Yogyakarta.

Untuk mewujudkan suatu lingkungan yang sehat maka harus memenuhi prinsip dan kriteria kesehatan. Hal ini penting supaya terbentukbudaya hidup sehat dan bersih bagi segenap stakeholder lingkungan masyarakat jogja, terciptanya pola hidup bersih secara individu dengan kehidupan nyata di masing-masing rumah tangga dan terciptanya kepedulian sosial terhadap lingkungan yang sehat.

Penyediaan minuman untuk umum termasuk di lingkungan warung pinggir jalan, sekolah, rumah makan/, restoran dituntut untuk memperhatikan aspek-aspek kualitas, kompetitif dalam harga dan keamanan minuman (Purnawijayanti, 2001). Keamanan minuman merupakan kebutuhan pokok masyarakat juga, karena minuman yang aman akan melindungi dan mencegah terjadinya penyakit atau gangguan kesehatan lainnya. Keamanan minuman saat ini terjadi isu utama bagi upaya membangun citra destinasimasyarakat. Belajar dari kejadian wabah kolera di Pulau Bali 1997 menunjukkan pentingnya pemahaman akan arti pentingnya sanitasi minuman. 
Hubungan antara kesehatan dan masyarakat sangat erat dan hampir tidak terpisahkan. Resiko kesehatan dapat juga timbul di lingkungan masyarakat terutama akibat minuman yang tidak higienis dikonsumsi masyarakat. Oleh sebab itu lingkungan masyarakt perlu terus didorong untuk menjadi lingkungan yang sehat. Maksudnya tidak lain untuk meningkatkan kesadaran pemberi jasa lingkungan maupun kesehatan dan masyarakat untuk memperbaiki mutu pelayanan dan upaya pencegahan penyebaran penyakit, terutama di kawasankawasan pariwisata. Dengan demikian destinasi lingkungan warung dapat menjadi tempat yang menawarkan pengalaman menarik, mutu lingkungan yang sehat dan jauh dari resiko penyakit.

Bakteri coliform merupakan parameter mikrobiolgis terpenting bagi kualitas air minum. Kelompok bakteri coliform ini antara lain terdiri atas Escherichia coli, Enterobacter aerogenesi dan citrobacter fruendii. Keberadaan bakteri coliform ini dalam air minum menunjukkan tingkat hygiene sanitasi yang rendah dan tidak berbahaya bagi kepentingan kesehatan, namun karena golongan ini sering terdapat dalam jumlah berlebihan dapat mempengaruhi rasa, bau, estetika dan warna. Bakteri coliform secara karakteristik menunjukkan adanya kuman di dalam air minum yang bersifat enteropatogenik atau yang bersifat berbahaya di dalam tubuh dan merupakan flora normal saluran pencemaran di dalam faeces, dimana faeces manusia merupakan media penyebaran bakteri coliform menyebabkan diare hingga muntaber ( Suprihatin, 2003 ).

\section{B. METODE PENELITIAN}

1. Tempat Penelitian : Tempat penelitian di Laboratorium STTL "YLH"

2. Tujuan dan manfaat Penelitian a. Tujuan

1) Mengetahui kualitas air baku ditinjau dari aspek mikrobiolgis kandungan (bakteri coliform) yang diproduksi oleh warung pembuat es batu di lingkungan warung jalan Timoho Yogyakarta yang mengacu pada SNI-38391995 tentang Mutu Es Batu dan Keputusan Menteri Kesehatan 907/MENKES/SK/VII/2 002 tentang Syarat-syarat dan Pengawasan Kualitas Air Minum dengan persyaratan tidak ada cemaran mikrobiologis bakteri coliform total dalam $100 \mathrm{ml}$ sampel.

2) Mengetahui kualitas es batu ditinjau dari aspek mikrobiologis kandungan (bakteri coliform) yang diproduksi oleh pedagang di lingkungan 
Pasar Kota Gede

Pemeriksaan dilaksanakan

Yogyakarta.

di Laboratorium STTL.

b. Manfaat

1) Dapat memberikan pengetahuan bagi masyarakat bahwa tidak semua es batu yang dijual dan dikonsumsi baik untuk kesehatan.

2) Dapat meningkatkan kesadaran masyarakat pentingnya sanitasi dan higienis pada proses pembuatan es batu

3) Memberikan informasi kepada masyarakat mengenai mutu es batu yang baik untuk dikonsumsi.

3. Tahap pelaksanaan penelitian.

a. Pengambilan sampel minuman dilaksanakan setelah minuman tersebut sudah disajikan. Pengambilan sampel diambil 3 jam setelah minuman dibuat, dengan perkiraan sudah ada pertumbuhan bakteri dalam minuman.

b. Pemeriksaan Laboratoriumn

Pemeriksaan minuman dilaksanakan untuk mengetahui ada tidaknya angka bakteri dalam sampel minuman.

4. Alat dan Bahan penelitian

a. Alat:

1) Timbangan

2) Pipet ukur $1 \& 10 \mathrm{ml}$

3) Inkubator

4) Tabung reaksi tertutup

5) Beaker 1 liter

6) Ose

7) Tabung durham

8) Autoclave

9) Pengaduk

b. Bahan :

1) Media kaldu llaktosa

2) Larutan HCL $0,1 \mathrm{~N}$

3) Larutan $\mathrm{NaOH} 0,1 \mathrm{~N}$

4) Aquades

5) Media BGLB

c. Sterilisasi Alat :Ambil botol sampel, tutup mulut botol dengan kapas, bungkus dengan aluminium foil/ kertas sampul/coklat., lalu ikat memakai benang

1) Ambil pipet ukur 10 $\mathrm{ml}$, dan $1 \mathrm{ml}$ masingmasing 3 buah, bungkus dengan kertas sampul coklat

2) Masukkan alat-alat tersebut ke dalam inkubator/oven

3) Sterilisasi pada suhu $121^{\circ} \mathrm{C}$ selama $2 \mathrm{jam}$ 
d. Pembuatan Media

Media Kaldu Laktose

Kepekatan $1 \mathrm{x}$

1) Timbang media kaldu laktosa sebanyak 13 gr, masukkan dalam bekerglass $1000 \mathrm{ml}$, tambahkan aquadest sampai batas.

2) Aduk sampai homogen, bila sulit larut bisa dibantu dengan pemanasan dalam water bath.

3) Atur $\mathrm{pH}$ 6,9 lebih kurang 0,1. Dengan $\mathrm{NaOH}$ atau HCL

4) Bila keruh perlu disaring

5) Masukkan ke dalam tabung reaksi masing-masing sebanyak $10 \mathrm{ml}$

6) Masukkan pula tabung $\quad 110 \quad{ }^{\circ} \mathrm{C}$ selama 10 -15 menit di dalam autoclave basah.

Catatan : $1 \quad \mathrm{x}$ analisa memerlukan 6 tabung (untuk metode 3 : 3 : 3)Media Kaldu Lactosa Kepekatan $3 \mathrm{x}$

1) Timbang media kaldu lactosa sebanyak 39 gr, dimasukkan dalam beaker glass $1000 \mathrm{ml}$ tambahkan aqudest sampai tanda batas.

2) Aduk sampai homogen, bila sulit bisa dibantu dengan pemanasan dalam water bath.

3) Atur $\mathrm{pH}$ 6,9 lebih kurang 0,1. Dengan $\mathrm{NaOH}$ atau HCL

4) Bila keruh perlu disaring.

5) Masukkan ke dalam tabung reaksi sebanyak $5 \mathrm{ml}$,

6) Masukkan pula tabung durham dengan posisinya, tutup dan siap disterilisasikan pada $110 \quad{ }^{\circ} \mathrm{C}$ selama autoclave basah.

Catatan : $1 \mathrm{x}$ analisa memerlukan 3 tabung (untuk metode 3:3:3).

e. Pembuatan Media BGLB

1) Timbang media Briliant Green Laktosan Brouth sebanyak 40 gr, dimasukkan dalam beaker glass $1000 \mathrm{ml}$ tambahkan aquades sampai tanda batas.

2) Aduk sampai homogen, bila sulit larut bisa dibantu 
dengan pemanasan dalam water bath.

3) Atur $\mathrm{pH}$ 6,9 lebih kurang 0,1 dengan Naoh atau HCL.

4) Bila keruh perlu disaring.

5) Masukkan ke dalam tabung reaksi sebanyak $5 \mathrm{ml}$.

6) Masukkan pula ke dalam tabung durham dengan dibalik posisinya, tutup dan siap disterilisasikan pada $110^{2}$ selama $10-15$ menit di dalam autoclave basah.

$\begin{array}{llll}\text { Catatan } & : & 1 & \mathrm{x}\end{array}$ analisamemerlukan 6 tabung (untuk metode $3: 3$ :3)

f. Pengambilan Sampel

1) Ambil botol yang telah steril, buka tali dan bungkusnya pada bagian mulutnya saja.

2) Buka mulut botol dan jidah apikan.

3) Isi botol sampai penuh, buang sebagian, sisakan 3/4 bagian dari botol, lidah apikan dan tutup kembali botol dengan kapas maupun

pembungkusnya.

4) Pemberian labe : Pengiriman, jenis \& asal sampel, waktu pengambilan.

5) Bawa ke laboratorium untuk segera dianalisa mikrobiologinya.

g. Jenis Test

Test Perkiraan

(Presimitive test)

1) Ambil sampel air yang akan dianalisa

2) Siapkan media lactoa steril sebanyak 9 buah, terdiri 6 tabung media Kepekatan $1 \mathrm{x}$ dan 2. tabung media kepekatan.

3) Susun tabung-tabung ke dalam rak dan nyalakan bunsen. Selama bekerja harus selalu dekat api dan hindarkan adanya kontaminasi.

4) Isi tabung dengan sampel menggunakan pipet ukur yang sudah disterilisasi sebagai berikut :

- $10 \mathrm{ml}$ ke dalam media laktosa kepekatan $3 \mathrm{x}$ 
sebanyak 3

tabung

- $1 \mathrm{ml}$ ke dalam

media laktosa

kepekatan $1 \quad \mathrm{x}$

sebanyak 3

tabung

- 0,1 ml ke dalam

media laktosa

$\begin{array}{lll}\text { kepekatan } & 1 & \mathrm{x}\end{array}$

sebanyak 3

tabung.

5) Lidah apikan tutup tabung lalu tutup

6) Goyang-goyang tabung agar

homogen

Catatan : tidak boleh ada gelembung udara dalam tabung durham.

7) Beri label pada masing-masing

tabung tersebut untuk menghindari kesalaan.

8) Ikat tabung tersebut, inkubasikan pada 35 oC selama 2 x 24 jam.

9) Cek hasil inkubasi, tunjukkan dengan adanya gas yang terbentuk dalam tabung durham, dinyatakan positip dan dilanjutkan ke test penegasan. Apabila dalam waktu 2 x 24 jam tidak terbentuk gas, test perkiraan dinyatakan negatip dan tidak dilanjutkan ke test penegasan.

h. Test

Penegasan

(Confirmed test)

1) Siapkan tabung yang berisi media BGLB sebanyak 2 x jumlah tabung yang menunjukkan peragian positip pada test perkiraan.

2) Siapkan juga tabungtabung yang menunjukkan peragian positip dari test perkiraan.

3) Masukkan 1 sampai 2 ose dari tabung yang menunjukkan peragian positip dari testperkiraan ke dalam tabung yang berisi media BGLB penginukulasian masing-masing tabung tersebut dilakukan sebanyak 2x (tabung a dan b). Catatan : Tidak boleh ada gelembung udara dalam tabung durham.

4) Setelah selesai penginokulasian, inkubasikan tabung 
durham dalam waktu 2 x 24 jam dinyatakan sebagai test penegasan positip, jika tidak terbentuk gas dinyatakan negatip.

5) Tabulasikan hasilhasil test tersebut dan cari angka coliform dari tabel.

\section{HASIL DAN PEMBAHASAN}

\section{HASIL}

Berdasarkan hasil observasi yang peneliti lakukan pada pedagang es batu yang menjual dagangan di lingkungan pasar Kota Gede Yogyakarta tidak memenuhi syarat kesehatan sesuai dengan Kepmenkes RI No. 942/Menks/SK/VII/2003. Walaupun pada prinsip nya pemilihan bahan-bahan yang digunakan oleh pedagang dalam pembuatan es batu, baik di pengepules, pengecer keliling, dan industri rumah tangga telah memenuhi syarat kesehatan. Hal ini dikarenakan/dimungkinkan dari faktor lain seperti tempat pengepul, proses pembungkusan (bungkus)/penjamah. Apabila dilihat dari tempat, alat penutup es batu yang dilakukan oleh pedagang es batu di lingkungan Pasar Kota Gede Yogyakarta tidak memenuhi syarat kesehatan sesuai dengan Kepmenkes RI/No.942/Menkes/SK/VII/2003.

Seluruh atau sebagian besar pedagang, pengepules, dan pengecer es batu tidak memakai tutup kepala, celemek, serta pakaian yang bersih dalam menjajakan/menjual es batu. Pedagang juga bercakap dalam menjajakan/menjual es batu. Sedangkan berdasarkan Kepmenkes RI No. 942/Menkes?SK/VII/2003 syarat-syarat penjamah/orang dalam menangani makanan, minuman antara lain :

1. Tidak menderita penyakit mudah menular, misalnya seperti batuk, pilek, diare, penyakit perut sejenisnya.

2. Menutup luka (pada luka terbuka), bersin.

3. Menjaga kebersihan tangan, rambut, kuku dan pakaian.

4. Memakai celemek dan tutup kepala.

5. Mencuci tangan setiap kali hendak menangani makanan atau minuman.

6. Menambah makanan, minuman harus memakai alat/perlengkapan atau alas tangan.

7. Tidak sambil merokok, menggaruk anggota badan (telinga, hidung, mulut, dan bagian lainnya).

8. Tidak batuk atau bersin dihadapan makanan atau miniman yang dijajakan atau disajikan dan atau tanpa menutup hidung (mulut).

Dari kesekian syarat menurut Kepmenkes tersebut di atas, berdasarkan pengamatan peneliti 
akibat dari es batu tersebut tidak memenuhi Kepmenkes RI No. 942/ Menkes/SK/VII/2003 dan

KepmenkesRI/No.907/Menkes/SK/V

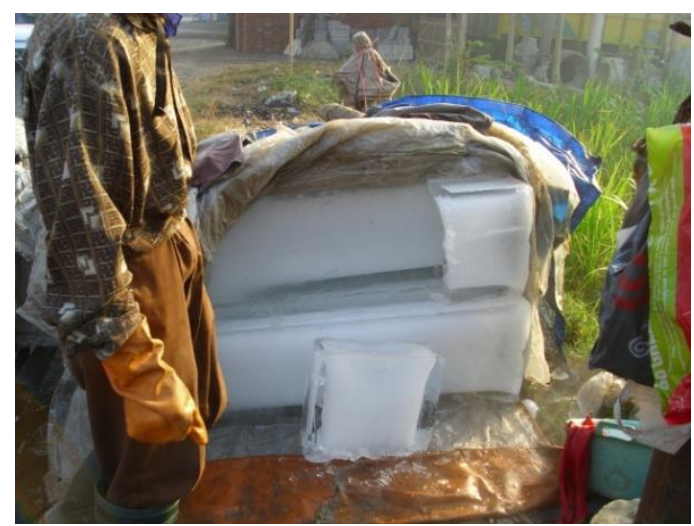

Gambar 1. Kondisi tempat / lokasi es batu

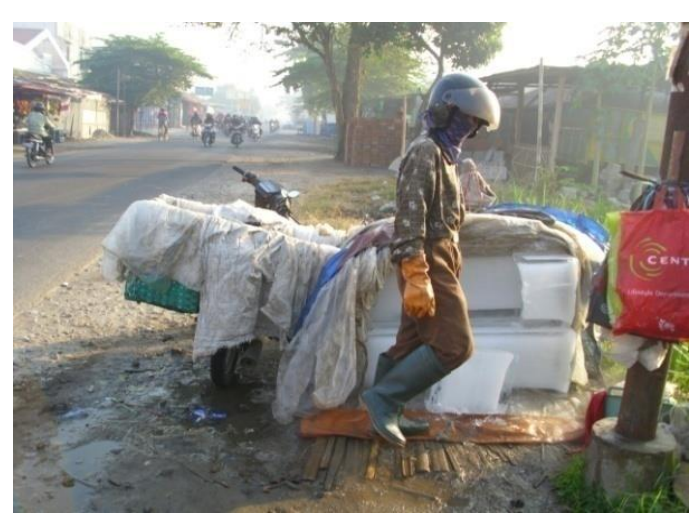

Gambar 2. Pengedar es batu yang memakai alas tangan
II/2002, yang mengakibatkan kandungan es batu mengandung atau terdapat colitinja. Sebagai contoh pada Gambar berikut ini.

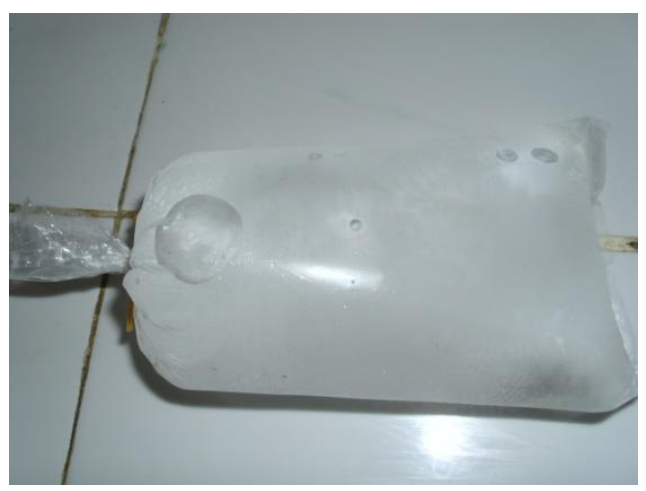

Gambar 3. Esbatukemasanplastik

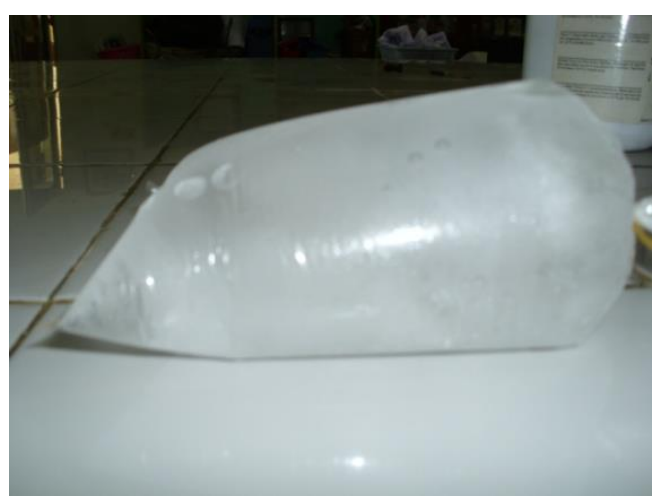

Gambar 4. Es batu dari hasil industri rumah tangga

Seharusnya para pedagang baik pengepul es, pengecer keliling, industry rumah tangga seperti pada gambar tersebut di atas minimal memenuhi syarat-syarat kesehatan harus menjaga kebersihan seperti pada alat-alat pembungkus es batu yang digunakan harus dijaga kebersihannya, dan seperti mencuci tangan, pakaian selalu bersih, tidak batuk, pilek dan sebagainya. dalam 
pengangkutan es batu seluruh pedagang harus menjaga kebersihan baik alat-alat yang digunakan, meletakkan es batu pada tempat yang tertutup, bersih, terhindar dari debu dan lain sebagainya.

\section{PEMBAHASAN}

Berdasarkan pengamatan peneliti baik tempat, penutup es batu tidak menjaga kebersihan seperti pada gambar 1 di atas. Para pedagang pengecer/penjaja/penjual tidak memakai seperti masker, penyajian yang dijajakan/dijual oleh pedagang di lingkungan pasar Kota Gede Yogyakarta tidak memenuhi syarat kesehatan akibat dari kekurang atau menjaga kebersihan baik dari pengepul, penjaja/penjual, pengecer es batu yang mengakibatkan es batu dapat terkontaminasi debu atau kotoran yang lain , juga karena bakteri yang terbawa oleh deb dan kotoran di udara yang kemudian lengket pada alat seperti penutup es batu.

Dari hasil laboratorium yaitu kesemua itu bisa dilihat pada hasil laboratorium Sekolah Tinggi Teknik Lingkungan Yogyakarta yang antara lain : Es batu dari pengepul untuk colitinjanya pada pengamatan sampel I atau sampel pertama terdapat colitinja sebesar 2400, MPN/100 ml, pengamatan sampel ke II dan pada pengamatan sampel ke III (tiga) sama yaitu sebesar 2400 MPN/100 $\mathrm{ml}$ yang seharusnya menurut Baku Mutu Air Bersih Kepmenkes RI
No.907/Menkes/SK/VII/2002 dan

Kepmenkes RI No.

942/Menkes/SK/VII/2003

seharusnya untuk colitinjanya 0 MPN/100 ml.

Berdasarkam hasil

laboratorium Sekolah Tinggi Teknik Lingkungan Yogyakarta, pada sampel 1 terdapat 2400 MPN/100 $\mathrm{ml}$, pada sampel 2 terdapat colitinja sebesar 1100, dan pada sampel 3 juga terdapat colitinja 1100 yang seharusnya menurut Kepmenkes RI colitinja seharusnya $0 \mathrm{MPN} / 100 \mathrm{ml}$, pada industri rumah tangga untuk sampel 1 terdapat colitinja sebesar 27 MPN/100 ml, dan pada sampel 2 terdapat colitinja sebesar 20 MPN/100 ml, sedangkan pada sampel 3 pada industri rumah tangga terdapat 27 MPN/100 ml, yang seharusnya pada minuman es batu menurut Kepmenkes RI No. 942/Menkes/SK/VII/2003 dan 907/Menkes/SK?VII/2002 colitinja tidak boleh lebih dari $0 \mathrm{MPN} / 100 \mathrm{ml}$. Jadi pada dasarnya es batu yang dijajakan/dijual baik dari pengecer es, pengepul dan industry rumah tangga masih mengandung colitinja, berdasarkan pengamatan peneliti karena disebabkan para pedagang tersebut kurang memperhatikan kebersihan terutama tempat dan penutup es batu seperti terlihat pada gambar/foto tersebut di atas, tetapi yang paling sedikit jumlah colitinja pada pembuatan es batu industri rumah tangga. 


\section{KESIMPULAN DAN SARAN}

\section{Kesimpulan}

Berdasarkan hasil observasi peneliti , es batu yang dijajakan/dijual di lingkungan pasar Kota Gede Yogyakarta dapat disimpulkan antara lain :

a. Penyimpanan es batu dari pengepul es tidak memenuhi syarat kesehatan.

b. Pengolahan, penyimpanan, pengangkutan, dan penyajian es batu yang diedarkan ke pasar Kota Gede Yogyakarta tidak memenuhi syarat kesehatan.

c. Kandungan colitinja pada es batu tersebut di atas melebihi syarat kesehatan yaitu di atas 0 MPN/100 ml.

\section{Saran}

a. Penyimpanan es batu dari pengepul pewadahan harus dijaga kebersihanya dan lokasi harus jauh dari sumber pencemar. I

b. Pengolahan, penyimpanan, pengangkutan, dan penyajian harus higienes.

c. Harus bebas dari kandungan colitinja

\section{F. DAFTAR PUSTAKA}

Adams. M, Motarjemi Y, 1999Basic Food Safety for Health Workers, World Health Organtation Switzerland

Anonim, 1995, Standar Nasional Indonesia, 01-3839-1995, E.
Batu. Dewan Standarisasi Nasional, Jakarta

Anonim, 2002, Syaratsyaratdanpengawasankualitas air minum, permenkes RI No. 907/Menkes/SK/VII/2002, Depkes RI, Jakarta

Anonim, 2003, Syaratsyaratdanpengawasankualitas air minum, permenkes RI No. 942/Menkes/SK/VII/2003, Depkes RI, Jakarta

Badan Pengawasan Obat dan Makanan, 2002, Materi penyuluhan keamanan pangan bagi penyuluh keamanan pangan industry rumah tangga, deputi bidang pengawasan keamanan pangan dan bahan berbahaya, Direktorat surveylan dan penyuluhan keamanan pangan, Jakarta.

Departemen Kesehatan Republik Indonesia, 1995, Batas maksimum cemaran mikroba dalam makanan, Direktorat Jenderal Pengawasan Obat dan Makanan, Bagian Proyek Peningkatan Pengendalian dan Peningkatan makanan.

Departemen Kesehatan Republik Indonesia, 2004, Pedoman bagi petugas dalam menyusun peraturan daerah tentang higiene sanitasi makanan dan minuman, Direktorat Penyehatan Air dan Sanitasi, Direktorat Pemberatasan Penyakit Menular dan Penyehatan Lingkungan, Jakarta.

Gaman, 1992, The Science of food, an introdution to food science nutrition and microbiology, second edition.Pergamon 
Press Plc, Headington Hill Hall, England.

Poejiadi, Anna, 1994, Dasardasarbiokimia, Universitas Indonesia Press, Jakarta.

Suriwiria, 1985, Pengantar Mikrobiologi umum, angkasa, Bandung.
Suriwiria, 1996, Mikrobiologi air, Penerbit, Alumni, Bandung. Subiroso Boy dkk, 2011, Sanitasi makanan dan minuman, menuju peningkatan mutu efisiensi rumah sakit, salemba medika. 